\title{
Investigating Water Use Efficiency of Potato in Chaharmahal and Bakhtiari Province Compared to Alternate Furrow Irrigation Method, Iran
}

\author{
Mohammad Shayannejad ${ }^{1}$, Kaveh Ostad-Ali-Askari ${ }^{* 2}$, Mahboubeh Amoushahi-Khouzani ${ }^{3}$, \\ Saeid Eslamian ${ }^{4}$, Vijay P. Singh ${ }^{5}$, Nicolas R. Dalezios ${ }^{6}$ \\ ${ }^{1,4}$ Water Engineering Department, Isfahan University of Technology, Isfahan, Iran. \\ ${ }^{2 *}$ Department of Civil Engineering, Isfahan (Khorasgan) Branch, Islamic Azad University, Isfahan, Iran. \\ ${ }^{3}$ Water Engineering Department, Science and Research Branch, Islamic Azad University, Tehran, Iran. \\ ${ }^{5}$ Department of Biological and Agricultural Engineering \& Zachry Department of Civil Engineering, Texas A \\ and M University, 321 Scoates Hall, 2117 TAMU, College Station, Texas 77843-2117, U.S.A. \\ ${ }^{6}$ Laboratory of Hydrology, Department of Civil Engineering, University of Thessaly, Volos, Greece \& \\ Department of Natural Resources Development and Agricultural Engineering, Agricultural University of \\ Athens, Athens, Greece.
}

*Corresponding Author: Dr. Kaveh Ostad-Ali-Askari, Department of Civil Engineering, Isfahan (Khorasgan) Branch, Islamic Azad University, Isfahan, Iran. Emails: koa.askari@khuisf.ac.ir , kaveh.oaa2000@gmail.com

\begin{abstract}
In order to achieve optimal use of water resources in agriculture and to increase water use efficiency, it is necessary to apply robust irrigation management particularly in surface methods. Deficit irrigation is an irrigation management method in which a technical-engineering method is used in order to supply the required water for irrigated plants so that the maximum use of water unit will be achieved. There are significant methods to apply deficit irrigation in surface irrigation and one method which has recently been used is alternate furrow irrigation. In this method in every round, the furrows are irrigated alternately; the water is collected in one side of planting rows and the wetting pattern will progress laterally as far as it can supply the required wet for unirrigated furrows. The more this progress, the more successful is irrigation. Therefore, this method is highly applicable in the soils with high degree of permeability and trivial slope because these characteristics would lead to increase in lateral progress. In this paper, effect of alternate furrow irrigation in a potato farm on water use efficiency was investigated through randomized complete block design $(R C B D)$. The results showed that this method would significantly increase water use efficiency. Moreover, in this study the water use efficiency of potato in Charahmahal and Bakhtiari Province was compared with the values obtained from alternate furrow irrigation method. The results indicated that water use efficiency in fixed alternate furrow irrigation had significantly difference with other methods. And this efficiency was higher than the efficiencies in different parts of the province.
\end{abstract}

Keywords: Alternate furrow irrigation, Water use efficiency.

\section{INTRODUCTION}

Potato is in category of strategic crops and because of starch and protein it has special nutritional value. According to Agricultural Statistics 1996, it covers approximately 145000 acres of cultivated lands in Iran, and total production of this crop exceeds 3 million tons (average 20 ton per acre). Potato is cultivated in most of the provinces including Ardebil, Azarbaijan, Hamadan, Isfahan, Tehran and Chaharmahal and Bakhtiari. Today, deficit irrigation is considered a method to optimal use of water resources in agriculture. This issue needs consideration in every plant and each region. For the past decades, the debate regarding this problem has continued and has attracted the attention of many researches. Here are some examples:

English et al (1990) cultivated the wheat under center pivot irrigation system during 9 years and concluded that: firstly, production function is quadratic and cost function is a linear function. Secondly, under deficit irrigation condition, profit per surface area unit was $25 \%$ less than full irrigation whereas profit per consumed water unit under deficit irrigation was $14.5 \%$ more than full 
irrigation. Thirdly, when there is land limitation and abundance of water, the full irrigation will not lead to maximal profit. Fourthly, there is a depth of consumed water in which profit (net income) resulted from it would be equal to full irrigation profit. In this study, it was obtained $35 \mathrm{~cm}$ (equivalent to 57\% depth of full irrigation). Stegman et al. (1990) indicated that although short-term water stress during early flowering may result in flower and pod drop in the lower canopy, increased pod set in the upper nodes compensates for this where there is a resumption of full irrigation. Sepaskhah and Kamgar Haghighi (1997) investigated deficit irrigation on sugar beet in Shiraz (in Iran, other studies on deficit irrigation have been conducted on crops such as wheat or sorghum but they are not included here for brevity). They applied deficit irrigation under method of alternate furrow irrigation. They used split plot as statistical plan in which irrigation method was considered as primary treatment and irrigation round as secondary treatment. The irrigation methods were as follow: normal furrow irrigation, fixed alternate furrow irrigation, and variable alternate furrow irrigation (in this method the furrows which are irrigated in one round, will not irrigate in the next round). They concluded that of these methods, the variable alternate furrow irrigation had the most water use efficiently.

Hengler et al (2000) applied deficit irrigation on cotton through subsurface drip feed irrigation in Texas. They used drip irrigation tapes alternately in planting rows to achieve deficit irrigation. Shock and Filbert (2000) examined deficit irrigation on different varieties of potato in Oregon State. They used split plot as statistical plan and irrigation treatments and varieties were acted as primary and secondary plots respectively. On deficit irrigation plots, the irrigation was performed when soil suction reached 0/6 atmosphere and depth of irrigation was considered equal to plant consumption. Krida (2000) obtained sensitivity factor of crop to water stress for different agricultural plants in Turkey using production functions for different crops and under different conditions. The results indicated that if irrigation was performed only in shoot growth stage, the mentioned factor would be less than when it was performed in flowering stage. The more this factor, the more sensitive the plant is to water stress. And it depends on type of plant, type of variety, irrigation method and growth stage or stages in which irrigation is applied.

\section{Material AND Methods}

This research was conducted on potato (Marphona) in research center of Chaharmahal and Bakhtiari province located in Shahrekord in 2004 as follow:

The statistical plan was randomized complete block design (RCBD) with three treatments of furrow irrigation (normal, fixed alternate, variable alternate) and four irritations. Overall, 12 plots in $4.5 * 10$ $\mathrm{m}$ are created and in each plot it is constructed six furrows with width $0 / 75 \mathrm{~m}$ length of $10 \mathrm{~m}$. During early days of June, the potatoes were cultivated on stacks with $30 \mathrm{~cm}$ interval and in depth of $10 \mathrm{~cm}$. the distance between plots was determined $1 \mathrm{~m}$. After germination, irrigation treatments were applied and volume of irrigation water for each furrow and lack of soil moisture relative to agricultural capacity was calculated by installing plaster blocks in root depth and measured by a meter. During shoot growth, the chemical fertilizers were used if necessary. The crop was harvested toward end of September. Finally, having determined volume of consumed water and amount of the yields, the water use efficiency was calculated and compared with other values in different parts of the province.

\section{RESUlts}

The values of water use efficiency (according to total weight of the yield) for different treatments and analysis of variance table are presented in table $1 \& 2$.

Table1: Values of water use efficiency in different treatments (in $\mathrm{kg} / \mathrm{sq} . \mathrm{m}$ )

\begin{tabular}{|c|l|l|l|l|l|}
\hline Irritation & \multicolumn{1}{|c|}{1} & \multicolumn{1}{|c|}{3} & \multicolumn{1}{c|}{ Mean } & \\
\hline Treatment & & & & & \\
\hline Normal (N) & $2 / 47$ & $2 / 98$ & $2 / 91$ & $3 / 13$ & $2 / 87$ \\
\hline Fixed alternate (F) & 3 & $2 / 95$ & $3 / 73$ & $3 / 84$ & $3 / 38$ \\
\hline Variable alternate (V) & $3 / 19$ & $3 / 08$ & $3 / 15$ & $3 / 48$ & $3 / 23$ \\
\hline
\end{tabular}

Table2: Results of Analysis of variance for water use efficiency

\begin{tabular}{|c|c|c|c|c|}
\hline Source of change & Degree of freedom & SS & MS & FS \\
\hline Block & 3 & $0 / 8718$ & $0 / 2962$ & $3 / 67$ \\
\hline
\end{tabular}


Investigating Water Use Efficiency of Potato in Chaharmahal and Bakhtiari Province Compared to Alternate Furrow Irrigation Method, Iran

\begin{tabular}{|c|c|c|c|c|}
\hline Treatment & 2 & $0 / 3706$ & $0 / 1853$ & $4 / 622$ \\
\hline Error & 6 & $0 / 55$ & $0 / 0917$ & \\
\hline Total & 11 & $1 / 7927$ & & \\
\hline
\end{tabular}

According to the table 2 and F- statistical distribution it is concluded that the difference between treatments is significant in 5\% level. Therefore, the alternate furrow irrigation leads to increase in water use efficiency. In this method, because of low level of consumed water compared to normal irrigation method, the area under cultivation could be increased.

The values for area under cultivation, performance and water use efficiency of potato during 2003 and 2004 in different parts of the province are presented in tables $3 \& 4$.

Table3: Conditions of potato cultivation in different parts of the province in 2003

\begin{tabular}{|l|l|l|l|l|}
\hline Region & $\begin{array}{l}\text { Area under cultivation } \\
\text { (acre) }\end{array}$ & $\begin{array}{l}\text { Production } \\
\text { (ton) }\end{array}$ & $\begin{array}{l}\text { Performance (kg / } \\
\text { acre) }\end{array}$ & $\begin{array}{l}\text { Water use efficiency } \\
\text { (kg /sq. m) }\end{array}$ \\
\hline Shahrekord & 1754 & 45280 & 25815 & $2 / 15$ \\
\hline Broujen & 2359 & 61741 & 26173 & $2 / 18$ \\
\hline Farsan & 24 & 676 & 28167 & $2 / 35$ \\
\hline Kouhrang & 323 & 7414 & 22954 & $1 / 91$ \\
\hline
\end{tabular}

Table4: Conditions of potato cultivation in different parts of the province in 2004

\begin{tabular}{|l|l|l|l|l|}
\hline Region & $\begin{array}{l}\text { Area under cultivation } \\
\text { (acre) }\end{array}$ & $\begin{array}{l}\text { Production } \\
\text { (ton) }\end{array}$ & $\begin{array}{l}\text { Performance (kg / } \\
\text { acre) }\end{array}$ & $\begin{array}{l}\text { Water use efficiency (kg } \\
\text { /sq. m) }\end{array}$ \\
\hline Shahrekord & 2793 & 75683 & 27097 & $2 / 26$ \\
\hline Broujen & 3804 & 61741 & 26173 & $2 / 16$ \\
\hline Farsan & 35 & 676 & 28167 & $2 / 14$ \\
\hline Kouhrang & 420 & 7414 & 22954 & $1 / 67$ \\
\hline
\end{tabular}

In Figure 1 values of water use efficiency of potato (according to total weight) in different parts of the province is compared to the results obtained from alternate furrow irrigation method.

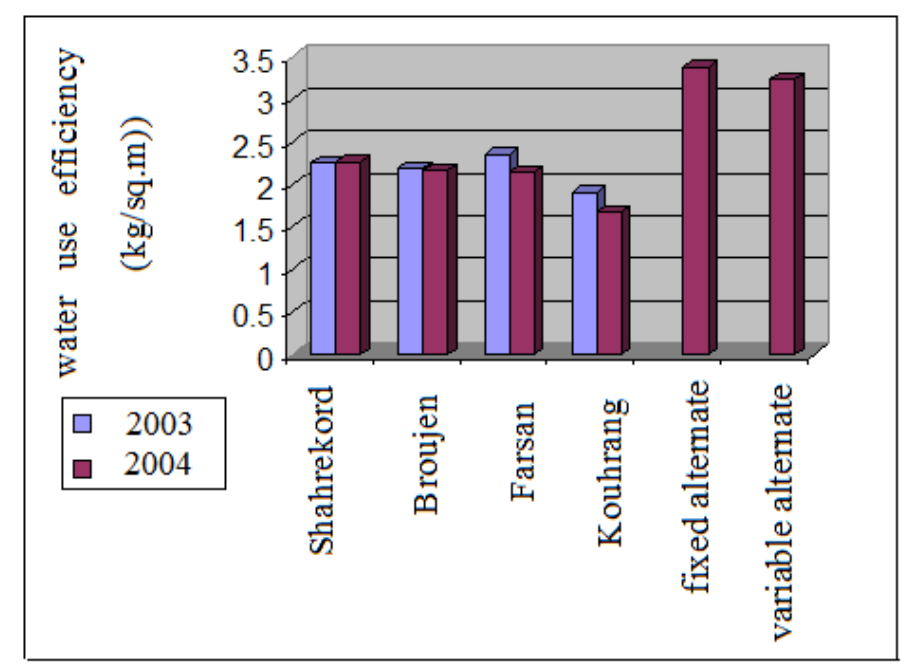

Figure1. Comparison of water use efficiency in different parts the province and alternate furrow irrigation method.

According to Figure 1, it is concluded that alternate furrow irrigation method has significant effect on increase of water use efficiency. This method increases the efficiency approximately 1.5 times and thus, the gross income will be increased as well. Given the fact that the consumed water in alternate furrow irrigation is half of the consumed water in normal method, therefore the area under cultivation could be increased up to 2 times. Moreover, the figure 1 suggests that fixed alternate furrow irrigation method is better than variable method. This method is easier to use too.

\section{REFERENCES}

[1] English, M., L. James.1990. Deficit irrigation II: Observations in Columbia basin.ASCE, J. of Irrigation and Drainage Engineering.116 (3):413-426. 
[2] Henggeler, J. C., J. M. Enciso, W. L. Multer, B. L. Unruh.2000. Deficit subsurface drip irrigation of corn. FAO. Deficit Irrigation Practices. Water Reports 22.

[3] Kirda, C. 2000. Deficit irrigation scheduling based on plant growth stages showing water stress tolerance. FAO. Deficit Irrigation Practices. Water Reports 22.

[4] Sepaskhah, A. R., A. A. Kamgar-Haghighi. 1997. Water use and yield of sugerbeet grown under everyother furrow irrigation with different irrigation intervals. Agricultural Water Management.34:71-79.

[5] Shock, C. C., E. B. G. Feibert. 2000. Deficit irrigation of potato. FAO. Deficit Irrigation Practices. Water Reports 22.

[6] Stegman, E. C., B. G. Schatz, J. C. Gardner.1990. Yield sensitivities of short season soybeans to irrigation management. Irrigation Science.11:111-119.

[7] The Crusade for Agriculture Organization, Chaharmahal and Bakhtiari Province, 2003. Fourth development Plan Act of Agriculture during 2004-2009.

[8] The Crusade for Agriculture Organization, Chaharmahal and Bakhtiari Province, 2003. Investigating capabilities and capacities of agriculture in province with a view to performance of organization and subsidiaries.

[9] Ostad-Ali-Askari, K., Shayannejad, M. 2015, Study of sensitivity of Autumnal wheat to under irrigation in Shahrekord, Shahrekord City, Iran. International Journal of Agriculture and Crop Sciences, 8 (4), $602-605$.

[10] Shayannejad, M., Akbari, N., Ostad-Ali-Askari, K. 2015, Study of modifications of the river physical specifications on muskingum coefficients, through employment of genetic algorithm. International Journal of Development Research, 5(3), 3782-3785.

[11] Ostad-Ali-Askari, K., Shayannejad, M. 2015, The Reviews of Einstein's Equation of Logarithmic Distribution Platform and the Process of Changes in the Speed Range of the Karkheh River, Khuzestan province, Iran. International Journal of Development Research, 5(3), 3786-3790.

[12] Ostad-Ali-Askari, K., Shayannejad, M., Ghorbanizadee-Kharazi, H. 2015, Assessment of artificial neural network performance and exponential regression in prediction of effective rainfall, International Journal of Development Research, 5(3), 3791-3794.

[13] Shayannejad, M. Akbari, N. and Ostad-Ali-Askari, K. 2015, Determination of the nonlinear Muskingum model coefficients using genetic algorithm and numerical solution of the continuity. Int. J. of Science: Basic and Applied Research, 21(1), 1-14.

[14] Ostad-Ali-Askari, K., Shayannejad, M. 2015, the Study of Mixture Design for Foam Bitumen and the Polymeric and Oil Materials Function in Loose Soils Consolidation. Journal of Civil Engineering Research, 5(2), 39-44. DOI: 10.5923/j.jce.20150502.04

[15] Sayedipour, M., Ostad-Ali-Askari, K., Shayannejad, M. 2015, Recovery of Runoff of the Sewage Refinery, a Factor for Balancing the Isfahan-Borkhar Plain Water Table in Drought Crisis Situation in Isfahan Province-Iran. American Journal of Environmental Engineering, 5(2): 43-46. DOI: 10.5923/j.ajee.20150502.02

[16] Ostad-Ali-Askari, K., Shayannejad, M. 2015, Developing an Optimal Design Model of Furrow Irrigation Based on the Minimum Cost and Maximum Irrigation Efficiency. International Bulletin of Water Resources \& Development, 3(2), 18-23.

[17] Ostad-Ali-Askari, K., Shayannejad, M. 2015, Presenting a Mathematical Model for Estimating the Deep Percolation Due to Irrigation. International Journal of Hydraulic Engineering, 4(1), 17-21. DOI: 10.5923/j.ijhe.20150401.03.

[18] Ostad-Ali-Askari, K., Shayannejad, M. 2015, Usage of rock fill dams in the HEC-RAS software for the purpose of controlling floods. American Journal of Fluid Dynamics, 5(1), 23-29. DOI: 10.5923/j.ajfd.20150501.03.

[19] Ostad-Ali- Askari, K., Shayannejad, M. 2015, the effect of heterogeneity due to inappropriate tillage on water advance and recession in furrow irrigation. Journal of Agricultural Science, 7(6), 127-136.

[20] Shayannejad, M., Ostad-Ali-Askari, K. 2015, Effects of magnetized municipal effluent on some chemical properties of soil in furrow irrigation. International Journal of Agriculture and Crop Sciences, 8(3), 482489.

[21] Ostad-Ali-Askari, K., Shayannejad, M. 2015, Optimal design of pressurized irrigation laterals installed on sloping land. International Journal of Agriculture and Crop Sciences, ISSN 2227-670X. 8(5), 792-797.

[22] Ostad-Ali-Askari K, Shayannejad M, Eslamian S, Navab-Pour B. 2016, Comparison of solution of SaintVenant equations by characteristics and finite difference methods for unsteady flow analyzing in open channel. International Journal of Hydrology Science and Technology, 6(3), 9-18. 
[23] Ostad-Ali-Askari K, Shayannejad M, Eslamian S, et al. 2017, Deficit Irrigation: Optimization Models. Management of Drought and Water Scarcity. Handbook of Drought and Water Scarcity, Taylor \& Francis Publisher, USA. Vol. 3. $1^{\text {th }}$ Edition, pp: 373-389.

[24] Eskandari S, Hoodaji M, Tahmourespour A, Abdollahi A, Mohammadian-Baghi T, Eslamian S, Ostad-AliAskari K. 2017, Bioremediation of Polycyclic Aromatic Hydrocarbons by Bacillus Licheniformis ATHE9 and Bacillus Mojavensis ATHE13 as Newly Strains Isolated from Oil-Contaminated Soil. Journal of Geography, Environment and Earth Science International, 11(2): 1-11.

[25] Shayannejad M, Ostad-Ali-Askari K, Eslamian S, et al. 2017, Development of a new method for determination of infiltration coefficients in furrow irrigation with natural non-uniformity of slope. Sustain. Water Resour. Manag. 3(2): 163-169.

[26] Shafaei-Bejestan M, Eslamian S, Marani-Barzani M, P. Singh V, Kazemi M, Ostad-Ali-Askari K. 2017 , Assessment of Drainage Slope on the Manning Coarseness Coefficient in Mountain Area. International Journal of Constructive Research in Civil Engineering (IJCRCE), 3(1): 33-40.

[27] Bahmanpour H, Awhadi S, Enjili J, Eslamian S, Ostad-Ali-Askari K. 2017, Optimizing Absorbent Bentonite and Evaluation of Contaminants Removal from Petrochemical Industries Wastewater. International Journal of Constructive Research in Civil Engineering (IJCRCE), 3(2): 34-42.

[28] Shayannejad M, Eslamian S, Gandomkar A, Marani-Barzani M, Amoushahi-Khouzani M, Majidifar Z, Rajaei-Rizi F, Kazemi M, P. Singh V, Dehghan SH, Shirvani-Dastgerdi H.R, Norouzi H, Ostad-Ali-Askari K. 2017, A Proper Way to Install Trapezoidal Flumes for Measurements in Furrow Irrigation Systems. International Journal of Research Studies in Agricultural Sciences (IJRSAS), 3(7): 1-5.

[29] Dehghan Sh, Kamaneh S.A.A., Eslamian S, Gandomkar A, Marani-Barzani M, Amoushahi-Khouzani M, Singh V.P., Ostad-Ali-Askari K. 2017, Changes in Temperature and Precipitation with the Analysis of Geomorphic Basin Chaos in Shiraz, Iran. International Journal of Constructive Research in Civil Engineering (IJCRCE), 3(2): 50-57.

[30] Eslamian S, Mirabbasi-Najafabadi R, Ostad-Ali-Askari K. Advance Engineering Statistics (Simulation and Modeling of Uncertainty and Sensitivity Analysis). Kankash Publisher. First Edition, 2017. ISBN: 978600-136-359-7. Isfahan, Iran.

[31] Ostad-Ali-Askari K, Shayannejad M. 2016, FLOOD ROUTING IN RIVERS BY MUSKINGUM'S METHOD WITH NEW ADJUSTED COEFFICIENTS. International Water Technology Journal, IWTJ, 6(3): 189-194.

[32] Ostad-Ali-Askari K, Shayannejad M, Ghorbanizadeh-Kharazi H. 2017, Artificial Neural Network for Modeling Nitrate Pollution of Groundwater in Marginal Area of Zayandeh-rood River, Isfahan, Iran. KSCE Journal of Civil Engineering, 21(1):134-140. Korean Society of Civil Engineers. DOI: 10.1007/s12205-016-0572-8.

[33] Shayannejad M, Ostad-Ali-Askari K, Ramesh A, Singh V.P., Eslamian S. 2017, Wastewater and Magnetized Wastewater Effects on Soil Erosion in Furrow Irrigation. International Journal of Research Studies in Agricultural Sciences (IJRSAS), 3(8): 1-14. http://dx.doi.org/10.20431/2454-6224.0308001.

[34] Shayannejad M, Soltani-Toudeshki A.R, Arab M.A, Eslamian S, Amoushahi-Khouzani M, MaraniBarzani M, Ostad-Ali-Askari K. 2017, A Simple Method for Land Grading Computations and its Comparison with Genetic Algorithm (GA) Method. International Journal of Research Studies in Agricultural Sciences (IJRSAS), 3(8): 26-38.

[35] Eslamian S, Ostad-Ali-Askari K, Soltani M. 2017, Climate Variability: Integration of Renewable Energy into Present and Future Energy Systems in Designing Residential Buildings. International journal of Rural Development, Environment and Health Research (IJREH), 1(2): 18-30.

[36] Shayannejad M, Ostad-Ali-Askari K, Eslamian S, et al. 2017, Flow Hydraulic Investigation of the Wastewater on the Soil and Magnetic Field Effects in This Field. International Journal of Constructive Research in Civil Engineering (IJCRCE), 3(3): 1-15.

[37] Shayannejad M, Eslamian S, Singh V.P., Ostad-Ali-Askari K, et al. 2017, Evaluation of Groundwater Quality for Industrial Using GIS in Mountainous Region of Isfahan Province, Koh-Payeh, Isfahan, Iran. International Journal of Constructive Research in Civil Engineering (IJCRCE), 3(3): 24-37.

[38] Eslamian S, P. Singh V, Ostad-Ali-Askari K, R. Dalezios N, Yihdego Y, et al. 2017, Assessment of Aridity Using Geographical Information System in Zayandeh-Roud Basin, Isfahan, Iran. International Journal of Mining Science (IJMS), 3(2): 49-61.

[39] Matouq, M., Amarneh, I. A., Kloub, N., Badran, O., Al-Duheisat, S. A. and S. S. Eslamian, 2009, Investigating the Effect of Combustion of Blending Jordanian Diesel Oil with Kerosene on Reducing the Environmental Impacts by Diesel Engine, International Journal of Ecological Economic \& Statistics, Special Issue on Basin Ecology and Environment (BEE), Vol. 13, No. W09, 79-87. 
[40] Bahmani, R., Eslamian, S. S., Naderi-Bani, M., Fahhian F., 2012, Investigating Maximum Rainfall Intensity on Peak Discharge using IDF curves and HEC-HMS model, Ninth International Conference on River Engineering, Ahvaz.

[41] Eslamian, S., Tarkesh-Isfahani, S., Malekpour, I., 2010, investigating heavy metals concentration of a wastewater treatment plant for agricultural and landscape reuses, Dryland Hydrology: Global Challenges Local Solutions, September 1-4, Westin La Paloma-Tucson, USA.

[42] Eslamian, S. S. and M. Afyuni, 2003, Investigating Nitrate Contamination In the Groundwater of Isfahan Plain, Iran, 5th International Congress of Turkish Society of Toxicology, Antalya, Turkey.

[43] Moravejalahkami, B., Mostafazadeh-Fard, B., Heidarpour, M., Abbasi, F., Eslamian, S. S. and E.VazquezFernandez, 2010, The effects of variable inflow hydrographs on water saving in furrow irrigation using zero-inertia model, International Conference on Environmental Science and Technology, Bangkok, Thailand.

[44] Coles, N. A. and Eslamian, S., 2017, Definition of Drought, Ch. 1 in Handbook of Drought and Water Scarcity, Vol. 1: Principles of Drought and Water Scarcity, Ed. by Eslamian S. and Eslamian F., Francis and Taylor, CRC Press, USA, 1-12.

[45] Dalezios, N. R., Dunkel, Z., Eslamian, S., 2017, Meteorological Drought Indices: Definitions, Ch. 3 in Handbook of Drought and Water Scarcity, Vol. 1: Principles of Drought and Water Scarcity, Ed. by Eslamian S. and Eslamian F., Francis and Taylor, CRC Press, USA, 24-44.

[46] Goyal, M. K. Gupta, V., Eslamian, S., 2017, Hydrological Drought: Water Surface and Duration Curve Indices, Ch. 4 in Handbook of Drought and Water Scarcity, Vol. 1: Principles of Drought and Water Scarcity, Ed. by Eslamian S. and Eslamian F., Francis and Taylor, CRC Press, USA, 45-72.

[47] Dalezios, N. R., Gobin, A., Tarquis Alfonso, A. M., and Eslamian, S., 2017, Agricultural Drought Indices: Combining Crop, Climate, and Soil Factors, Ch. 5 in Handbook of Drought and Water Scarcity, Vol. 1: Principles of Drought and Water Scarcity, Ed. by Eslamian S. and Eslamian F., Francis and Taylor, CRC Press, USA, 73-90.

[48] TishehZan, P. and Eslamian, S., 2017, Agricultural Drought: Organizational Perspectives, Ch. 6 in Handbook of Drought and Water Scarcity, Vol. 1: Principles of Drought and Water Scarcity, Ed. by Eslamian S. and Eslamian F., Francis and Taylor, CRC Press, USA, 91-108.

[49] Bazrkar, M. H., Eslamian, S., 2017, Ocean Oscillation and Drought Indices: Application, Ch. 8 in Handbook of Drought and Water Scarcity, Vol. 1: Principles of Drought and Water Scarcity, Ed. by Eslamian S. and Eslamian F., Francis and Taylor, CRC Press, USA, 127-136.

[50] Basu, R., Singh, C. K., Eslamian, S., 2017, Cause and Occurrence of Drought, Ch. 9 in Handbook of Drought and Water Scarcity, Vol. 1: Principles of Drought and Water Scarcity, Ed. by Eslamian S. and Eslamian F., Francis and Taylor, CRC Press, USA, 137-148.

[51] Bazrafshan, J., Hejabi, S., Eslamian, S., 2017, Drought Modeling Examples, Ch. 11 in Handbook of Drought and Water Scarcity, Vol. 1: Principles of Drought and Water Scarcity, Ed. by Eslamian S. and Eslamian F., Francis and Taylor, CRC Press, USA, 167-188.

[52] Jonathan Peter Cox, Sara Shaeri Karimi, Eslamian, S., 2017, Real-Time Drought Management, Ch. 13 in Handbook of Drought and Water Scarcity, Vol. 1: Principles of Drought and Water Scarcity, Ed. by Eslamian S. and Eslamian F., Francis and Taylor, CRC Press, USA, 209-216.

[53] Garg, V. and Eslamian, S., 2017, Monitoring, Assessment, and Forecasting of Drought Using Remote Sensing and the Geographical Information System. Ch. 14 in Handbook of Drought and Water Scarcity, Vol. 1: Principles of Drought and Water Scarcity, Ed. by Eslamian S. and Eslamian F., Francis and Taylor, CRC Press, USA, 217-252.

[54] Dalezios, N. R., Tarquis Alfonso, A. M., and Eslamian, S., 2017, Drought Assessment and Risk Analysis, Ch. 18 in Handbook of Drought and Water Scarcity, Vol. 1: Principles of Drought and Water Scarcity, Ed. by Eslamian S. and Eslamian F., Francis and Taylor, CRC Press, USA, 323-344.

[55] Dalezios, N. R., Spyropoulosand, N. V., Eslamian, S., 2017, Remote Sensing in Drought Quantification and Assessment, Ch. 21 in Handbook of Drought and Water Scarcity, Vol. 1: Principles of Drought and Water Scarcity, Ed. by Eslamian S. and Eslamian F., Francis and Taylor, CRC Press, USA, 377-396.

[56] Araghinejad, S., Hosseini-Moghari, S. M., Eslamian, S., 2017, Application of Data-Driven Models in Drought Forecasting, Ch. 23 in Handbook of Drought and Water Scarcity, Vol. 1: Principles of Drought and Water Scarcity, Ed. by Eslamian S. and Eslamian F., Francis and Taylor, CRC Press, USA, 423-440.

[57] Vafakhah, M., and Eslamian, S., 2017, Application of Intelligent Technology in Rainfall Analysis, Ch. 24 in Handbook of Drought and Water Scarcity, Vol. 1: Principles of Drought and Water Scarcity, Ed. by Eslamian S. and Eslamian F., Francis and Taylor, CRC Press, USA, 441-460. 
[58] Vafakhah, M., Akbari Majdar, H. and Eslamian, S., 2017, Rainfall Prediction Using Time Series Analysis, Ch. 28 in Handbook of Drought and Water Scarcity, Vol. 1: Principles of Drought and Water Scarcity, Ed. by Eslamian S. and Eslamian F., Francis and Taylor, CRC Press, USA, 517-540.

[59] González, M. H., Garbarini, E. M., Rolla, A. L., and Eslamian, S., 2017, Meteorological Drought Indices: Rainfall Prediction in Argentina, Ch. 29 in Handbook of Drought and Water Scarcity, Vol. 1: Principles of Drought and Water Scarcity, Ed. by Eslamian S. and Eslamian F., Francis and Taylor, CRC Press, USA, 541-570.

[60] Hadizadeh, R. and Eslamian, S., 2017, Modeling Hydrological Process by ARIMA-GARCH Time Series, Ch. 30 in Handbook of Drought and Water Scarcity, Vol. 1: Principles of Drought and Water Scarcity, Ed. by Eslamian S. and Eslamian F., Francis and Taylor, CRC Press, USA, 571-590.

[61] Mujere, N., Yang, X. and Eslamian, S., 2017, Gradation of Drought-Prone Area, Ch. 31 in Handbook of Drought and Water Scarcity, Vol. 1: Principles of Drought and Water Scarcity, Ed. by Eslamian S. and Eslamian F., Francis and Taylor, CRC Press, USA, 591-606.

[62] Mahmudul Haque, M., Amir Ahmed, A., Rahman, A., Eslamian, S., 2017, Drought Losses to Local Economy, Ch. 33 in Handbook of Drought and Water Scarcity, Vol. 1: Principles of Drought and Water Scarcity, Ed. by Eslamian S. and Eslamian F., Francis and Taylor, CRC Press, USA, 627-642.

[63] Fakhruddin, B. S. H. M., Eslamian, S., 2017, Analysis of Drought Factors Affecting the Economy, Ch. 34 in Handbook of Drought and Water Scarcity, Vol. 1: Principles of Drought and Water Scarcity, Ed. by Eslamian S. and Eslamian F., Francis and Taylor, CRC Press, USA, 643-656.

[64] Dalezios, N. R., Eslamian, S., 2017, Environmental Impacts of Drought on Desertification Classification, Ch. 3 in Handbook of Drought and Water Scarcity, Vol. 2: Environmental Impacts and Analysis of Drought and Water Scarcity, Ed. by Eslamian S. and Eslamian F., Francis and Taylor, CRC Press, USA, 45-64.

[65] Nazif, S. and Tavakolifar, H., Eslamian, S., 2017, Climate Change Impact on Urban Water Deficit, Ch. 5 in Handbook of Drought and Water Scarcity, Vol. 2: Environmental Impacts and Analysis of Drought and Water Scarcity, Ed. by Eslamian S. and Eslamian F., Francis and Taylor, CRC Press, USA, 81-106.

[66] Shahid, S., Alamgir, M., Wang, X.-J., Eslamian, S., 2017, Climate Change Impacts on and Adaptation to Groundwater, Ch. 6 in Handbook of Drought and Water Scarcity, Vol. 2: Environmental Impacts and Analysis of Drought and Water Scarcity, Ed. by Eslamian S. and Eslamian F., Francis and Taylor, CRC Press, USA, 107-124.

[67] Orimoogunje, O. O. I., Eslamian, S., 2017, Minimizing the Impacts of Drought, Ch. 8 in Handbook of Drought and Water Scarcity, Vol. 2: Environmental Impacts and Analysis of Drought and Water Scarcity, Ed. by Eslamian S. and Eslamian F., Francis and Taylor, CRC Press, USA, 143-162.

[68] Maleksaeidi, H., Keshavarz, M., Karami, E., Eslamian, S., 2017, Climate Change and Drought: Building Resilience for an Unpredictable Future, Ch. 9 in Handbook of Drought and Water Scarcity, Vol. 2: Environmental Impacts and Analysis of Drought and Water Scarcity, Ed. by Eslamian S. and Eslamian F., Francis and Taylor, CRC Press, USA, 163-186.

[69] Reyhani, M. N., Eslamian, S., Davari, A., 2017, Sustainable Agriculture: Building Social-Ecological Resilience, Ch. 10 in Handbook of Drought and Water Scarcity, Vol. 2: Environmental Impacts and Analysis of Drought and Water Scarcity, Ed. by Eslamian S. and Eslamian F., Francis and Taylor, CRC Press, USA, $187-204$.

[70] Crusberg, T. C., Eslamian, S., 2017, Drought and Water Quality, Ch. 11 in Handbook of Drought and Water Scarcity, Vol. 2: Environmental Impacts and Analysis of Drought and Water Scarcity, Ed. by Eslamian S. and Eslamian F., Francis and Taylor, CRC Press, USA, 205-218.

[71] Gaaloul, N., Eslamian, S., and Laignel, B., 2017, Contamination of Groundwater in Arid and Semiarid Lands, Ch. 16 in Handbook of Drought and Water Scarcity, Vol. 2: Environmental Impacts and Analysis of Drought and Water Scarcity, Ed. by Eslamian S. and Eslamian F., Francis and Taylor, CRC Press, USA, 291-314.

[72] Banjoko, B., Eslamian, S., 2017, Sanitation in Drought, Ch. 17 in Handbook of Drought and Water Scarcity, Vol. 2: Environmental Impacts and Analysis of Drought and Water Scarcity, Ed. by Eslamian S. and Eslamian F., Francis and Taylor, CRC Press, USA, 315-330.

[73] Davari, A., Bagheri, A., Reyhani, M. N., Eslamian, S., 2017, Environmental Flows Assessment in Scarce Water Resources, Ch. 18 in Handbook of Drought and Water Scarcity, Vol. 2: Environmental Impacts and Analysis of Drought and Water Scarcity, Ed. by Eslamian S. and Eslamian F., Francis and Taylor, CRC Press, USA, 331-352.

[74] Qian, Q., Eslamian, S., 2017, Streamflow Quality in Low-Flow Conditions, Ch. 20 in Handbook of Drought and Water Scarcity, Vol. 2: Environmental Impacts and Analysis of Drought and Water Scarcity, 
Ed. by Eslamian S. and Eslamian F., Francis and Taylor, CRC Press, USA, 375-386.

[75] Mohammadzade Miyab, N., Eslamian, S., Dalezios, N. R., 2017, River Sediment in Low Flow Condition, Ch. 21 in Handbook of Drought and Water Scarcity, Vol. 2: Environmental Impacts and Analysis of Drought and Water Scarcity, Ed. by Eslamian S. and Eslamian F., Francis and Taylor, CRC Press, USA, 387-408.

[76] Pérez-Blanco, C. D., Delacámara., G., Gómez., C. M., Eslamian, S., 2017, Crop Insurance in Drought Conditions, Ch. 23 in Handbook of Drought and Water Scarcity, Vol. 2: Environmental Impacts and Analysis of Drought and Water Scarcity, Ed. by Eslamian S. and Eslamian F., Francis and Taylor, CRC Press, USA, 423-444.

[77] Kahrizi, D., Esfahani, K., Ashraf Mehrabi, A., Ghaheri, M., Azizi Aram, Z., Khosravi, S., Eslamian, S., 2017, Biotechnology for Drought Improvement, Ch. 24 in Handbook of Drought and Water Scarcity, Vol. 2: Environmental Impacts and Analysis of Drought and Water Scarcity, Ed. by Eslamian S. and Eslamian F., Francis and Taylor, CRC Press, USA, 445-460.

[78] Wade, P., Eslamian, S., 2017, Water Issues from a System Dynamics Perspective, Ch. 25 in Handbook of Drought and Water Scarcity, Vol. 2: Environmental Impacts and Analysis of Drought and Water Scarcity, Ed. by Eslamian S. and Eslamian F., Francis and Taylor, CRC Press, USA, 461-488.

[79] Rahman, A., Hajani, E., Eslamian, S., 2017, Rainwater Harvesting in Arid Regions of Australia, Ch. 26 in Handbook of Drought and Water Scarcity, Vol. 2: Environmental Impacts and Analysis of Drought and Water Scarcity, Ed. by Eslamian S. and Eslamian F., Francis and Taylor, CRC Press, USA, 489-500.

[80] Mukherjee, S., Yadav, K., Eslamian, S., 2017, Soil Contaminations in Arid and Semiarid Land, Ch. 29 in Handbook of Drought and Water Scarcity, Vol. 2: Environmental Impacts and Analysis of Drought and Water Scarcity, Ed. by Eslamian S. and Eslamian F., Francis and Taylor, CRC Press, USA, 547-556.

[81] Dayani, S., Sabzalian, M. R., Hadipour, M. Eslamian, S., 2017, Water Scarcity and Sustainable Urban Green Landscape, Ch. 30 in Handbook of Drought and Water Scarcity, Vol. 2: Environmental Impacts and Analysis of Drought and Water Scarcity, Ed. by Eslamian S. and Eslamian F., Francis and Taylor, CRC Press, USA, 557-604.

[82] Gohari, A., Zareian, M. J., Eslamian, S., Nazari, R. 2017, Interbasin Transfers of Water: Zayandeh-Rud River Basin, Ch. 32 in Handbook of Drought and Water Scarcity, Vol. 2: Environmental Impacts and Analysis of Drought and Water Scarcity, Ed. by Eslamian S. and Eslamian F., Francis and Taylor, CRC Press, USA, 619-630.

[83] Banjoko, B., Eslamian, S., 2017, Environmental Evaluation: Lessons Learned from Case Studies, Ch. 33 in Handbook of Drought and Water Scarcity, Vol. 2: Environmental Impacts and Analysis of Drought and Water Scarcity, Ed. by Eslamian S. and Eslamian F., Francis and Taylor, CRC Press, USA, 631-664.

[84] Abbasova, D., Eslamian, S., Nazari, R., 2017, Paleo-Drought: Measurements and Analysis, Ch. 34 in Handbook of Drought and Water Scarcity, Vol. 2: Environmental Impacts and Analysis of Drought and Water Scarcity, Ed. by Eslamian S. and Eslamian F., Francis and Taylor, CRC Press, USA, 665-674.

[85] Yihdego, Y., Eslamian, S., 2017, Drought Management: Initiatives and Objectives, Ch. 1 in Handbook of Drought and Water Scarcity, Vol. 3: Management of Drought and Water Scarcity, Ed. by Eslamian S. and Eslamian F., Francis and Taylor, CRC Press, USA, 1-26.

[86] Tuncok, I. K., Eslamian, S., 2017, Drought Management Strategies in Water-Stressed/Water-Scarce Regions, Ch. 5 in Handbook of Drought and Water Scarcity, Vol. 3: Management of Drought and Water Scarcity, Ed. by Eslamian S. and Eslamian F., Francis and Taylor, CRC Press, USA, 97-154.

[87] Reinstädtler, S., Islam, S. N., Eslamian, S., 2017, Drought Management for Landscape and Rural Security, Ch. 8 in Handbook of Drought and Water Scarcity, Vol. 3: Management of Drought and Water Scarcity, Ed. by Eslamian S. and Eslamian F., Francis and Taylor, CRC Press, USA, 195-234.

[88] Dalezios, N. R., Eslamian, S., 2017, Drought Assessment and Management for Heat Waves Monitoring, Ch. 9 in Handbook of Drought and Water Scarcity, Vol. 3: Management of Drought and Water Scarcity, Ed. by Eslamian S. and Eslamian F., Francis and Taylor, CRC Press, USA, 235-260.

[89] Kruse, E., Eslamian, S., 2017, Groundwater Management in Drought Conditions, Ch. 11 in Handbook of Drought and Water Scarcity, Vol. 3: Management of Drought and Water Scarcity, Ed. by Eslamian S. and Eslamian F., Francis and Taylor, CRC Press, USA, 275-282.

[90] Araghinejad, S., Hosseini-Moghari, S.-M., Eslamian, S., 2017, Reservoir Operation during Drought, Ch. 12 in Handbook of Drought and Water Scarcity, Vol. 3: Management of Drought and Water Scarcity, Ed. by Eslamian S. and Eslamian F., Francis and Taylor, CRC Press, USA, 283-292.

[91] Eslamian, S., Khosravi, B., Sayahi, M., Haeri-Hamedani, M. 2017, Crises Management Planning and Drought Management Plans, Ch. 13 in Handbook of Drought and Water Scarcity, Vol. 3: Management of Drought and Water Scarcity, Ed. by Eslamian S. and Eslamian F., Francis and Taylor, CRC Press, USA 
[92] Halbac-Cotoara-Zamfir, R., Eslamian, S., 2017, Functional Analysis of Regional Drought Management, Ch. 14 in Handbook of Drought and Water Scarcity, Vol. 3: Management of Drought and Water Scarcity, Ed. by Eslamian S. and Eslamian F., Francis and Taylor, CRC Press, USA, 305-328.

[93] Zahraei, A., Saadati, S., Eslamian, S., 2017, Irrigation Deficit: Farmlands, Ch. 16 in Handbook of Drought and Water Scarcity, Vol. 3: Management of Drought and Water Scarcity, Ed. by Eslamian S. and Eslamian F., Francis and Taylor, CRC Press, USA, 343-358.

[94] Amiri, M. J., Eslamian, S., Bahrami, M., Yousefi, N. 2017, Deficit Irrigation: Greenhouse, Ch. 17 in Handbook of Drought and Water Scarcity, Vol. 3: Management of Drought and Water Scarcity, Ed. by Eslamian S. and Eslamian F., Francis and Taylor, CRC Press, USA, 359-372.

[95] Ostad-Ali-Askari, K., Shayanejad, M., Eslamian, S., Zamani, F., Shojaei, N., Navabpour, B., Majidifard, Z., Sadri, A., Ghasemi-Siani, Z., Nourozi, H., Vafaei, O., Homayouni. S.-M.-A., 2017, Deficit Irrigation: Optimization Models, Ch. 18 in Handbook of Drought and Water Scarcity, Vol. 3: Management of Drought and Water Scarcity, Ed. by Eslamian S. and Eslamian F., Francis and Taylor, CRC Press, USA, 373-390.

[96] Eludoyin, A. O., Eludoyin, O. M., Eslamian, S., 2017, Drought Mitigation Practices, Ch. 19 in Handbook of Drought and Water Scarcity, Vol. 3: Management of Drought and Water Scarcity, Ed. by Eslamian S. and Eslamian F., Francis and Taylor, CRC Press, USA, 391-402

[97] Irshad, S. M., Eslamian, S., 2017, Politics of Drought Management and Water Control in India, Ch. 22 in Handbook of Drought and Water Scarcity, Vol. 3: Management of Drought and Water Scarcity, Ed. by Eslamian S. and Eslamian F., Francis and Taylor, CRC Press, USA, 447-460.

[98] Pati, R., Eslamian, S., 2017, Drought Management for Horticultural Crops in India, Ch. 23 in Handbook of Drought and Water Scarcity, Vol. 3: Management of Drought and Water Scarcity, Ed. by Eslamian S. and Eslamian F., Francis and Taylor, CRC Press, USA, 461-482.

[99] Khan, S., Eslamian, S., 2017, Ch. 25 in Handbook of Drought and Water Scarcity, Vol. 3: Management of Drought and Water Scarcity, Ed. by Eslamian S. and Eslamian F., Francis and Taylor, CRC Press, USA, 495-526.

[100]Sedaei, L., Sedaei, N., Cox, J. P., Dalezios N. R., Eslamian, S., 2017, Forest Fire Mitigation under Water Shortage, Ch. 26 in Handbook of Drought and Water Scarcity, Vol. 3: Management of Drought and Water Scarcity, Ed. by Eslamian S. and Eslamian F., Francis and Taylor, CRC Press, USA, 527-550.

[101]Torabi Farsani, N., Neto de Carvalho, C., Eslamian, S., 2017, Education Program for Drought, Ch. 27 in Handbook of Drought and Water Scarcity, Vol. 3: Management of Drought and Water Scarcity, Ed. by Eslamian S. and Eslamian F., Francis and Taylor, CRC Press, USA, 551-566.

[102]Nazif, S. and Tavakolifar, H., Eslamian, S., 2017, Emergency Drought Consequence Plan, Ch. 30 in Handbook of Drought and Water Scarcity, Vol. 3: Management of Drought and Water Scarcity, Ed. by Eslamian S. and Eslamian F., Francis and Taylor, CRC Press, USA, 640-658

[103]Mohseni Saravi, M., Shabazi, R., Eslamian, S., 2017, Coping with Drought- Ch. 31 in Handbook of Drought and Water Scarcity, Vol. 3: Management of Drought and Water Scarcity, Ed. by Eslamian S. and Eslamian F., Francis and Taylor, CRC Press, USA, 659-673

[104]Eslamian, S., Mohri-Isfahani, E., Mahdavi, A., Rajaei-Rizi, F., Marzi-Nouhedani, M., Ghasemi-Zanyani, M., Dehghani, S., Hosseini-Teshnizi., S. Z., Esmaeili, F., Shojaei, N., Ghane, M., Hasantabar-Amiri, A., 2017, Integrated Water Resources Management under Water Scarcity, Ch. 32 in Handbook of Drought and Water Scarcity, Vol. 3: Management of Drought and Water Scarcity, Ed. by Eslamian S. and Eslamian F., Francis and Taylor, CRC Press, USA, 675-695.

[105]Aghaei, A., Eslamian, S., Dalezios, N. R., Saeidi-Rizi, A., Bahrebardar, S., 2017, Drought and Dust Management, Ch. 33 in Handbook of Drought and Water Scarcity, Vol. 3: Management of Drought and Water Scarcity, Ed. by Eslamian S. and Eslamian F., Francis and Taylor, CRC Press, USA, 696-705.

[106]Eslamian, S., Dalezios, N. R., Singh, V. P., Adamowaski, J., Mohamadifard, S., Bahmani, R., Eskandari, S., Zomorodian, M., Arefeyan, A., Dehghani, S., Aghaesmaeili, M., Shahbazi, M., Amoushahi, M. T., Yousefi, N., Namdi, A., 2017, Drought Management: Current Challenges and Future Outlook, Ch. 34 in Handbook of Drought and Water Scarcity, Vol. 3: Management of Drought and Water Scarcity, Ed. by Eslamian S. and Eslamian F., Francis and Taylor, CRC Press, USA.

[107]Eslamian, S., Davari, A., and Reyhani, M. N., 2017, Iranian Qanāts: An Ancient and Sustainable Water Resources Utilization, Ch. 9, in Underground Aqueducts Handbook, Ed. By Angelakis A. N. et al., Taylor and Francis, CRC Group, 123-150.

[108]Khan, S., and Eslamian , S., 2017, Managing Drought through Qanāt and Water Conservation in Afghanistan, Ch. 22, in Underground Aqueducts Handbook, Ed. By Angelakis A. N. et al., Taylor and Francis, CRC Group, 385-402. 
[109]Wessels, J. I., Vardakos, S., Weingartner, H., Eslamian, S., Angelakis, A. N., 2017, Underground Aqueducts: Past, Present, and Future Trends, Ch. 29 in Underground Aqueducts Handbook, Ed. By Angelakis A. N. et al., Taylor and Francis, CRC Group, 491-510.

[110]Dalezios, N.R., Tarquis, A. M. and Eslamian, S. 2017: Droughts. Chapter 5, in book: Environmental Hazards Methodologies for Risk Assessment and Management. Editor: Dalezios, N. R., International Water Association Publishing, London, UK, 177-210.sss

[111]Dalezios, N. R. and Eslamian, S, 2017, Environmental Hazards Methodologies for Risk Assessment and Management, Ed. By Dalezios, N. R., IWA Publishing,

[112]Bazrkar, M. H., Adamowski, J., Eslamian, S., 2017, Water System Modeling, in Mathematical Advances Towards Sustainable Environmental Systems, Ed. by Furze, J.N., Swing, K., Gupta, A.K., McClatchey, R., Reynolds, D., Springer International Publishing, Switzerland, 61-88.

[113]Zareeian, M.J., Eslamian, S., Gohari, A., and Adamowski, J. 2017. The Effect of Climate Change on Watershed Water Balance, in Mathematical Advances Towards Sustainable Environmental Systems, Ed. by Furze, J.N., Swing, K., Gupta, A.K., McClatchey, R., Reynolds, D., Springer International Publishing, Switzerland, 215-238.

[114]Bazrkar, M. H., Zamani, N., Eslamian, S., Eslamian, A., Dehghan, Z., 2015, Urbanization and Climate Change, Handbook of Climate Change Adaptation, Ed. By Leal Filho, W., Springer, 619-655.

[115]Gohari, A., Zareeian, M. J. and Eslamian, S., 2015, A multi-model framework for climate change impact assessment, Handbook of Climate Change Adaptation, Ed. By Leal Filho, W., Springer, 17-35.

[116]Chen, Z., Ngo, H. H., Guo,W, and Eslamian, S., 2015, Water Shortages, in Urban Water Reuse Handbook, Ch. 1, Ed. By Eslamian, S., Taylor and Francis, CRC Group, USA, 3-14.

[117]Boogaard, F. and Eslamian, S., 2015, Water Reuse and Sustainable Urban Drainage Systems, in Urban Water Reuse Handbook, Ch. 4, Ed. By Eslamian, S., Taylor and Francis, CRC Group, USA, 37-44.

[118] Shah Naqvi, S. A. A., Sultan, A., and Eslamian, S., 2015, Water Quality Issues in Urban Water, in Urban Water Reuse Handbook, Ch. 8, Ed. By Eslamian, S., Taylor and Francis, CRC Group, USA, 99-112.

[119]Kumar Singh, Ch., Jha, N., and Eslamian, S., 2015, Reuse, Potable Water, and Possibilities, in Urban Water Reuse Handbook, Ch. 9, Ed. By Eslamian, S., Taylor and Francis, CRC Group, USA, 113-126.

[120]Kohansal, M. M., Saadati, S., Tarkesh Esfahany, S., and Eslamian, S., 2015, Urban Water Reuse in Industry, in Urban Water Reuse Handbook, Ch. 11, Ed. By Eslamian, S., Taylor and Francis, CRC Group, USA, 137-148.

[121]Kumar, M., Chidambaram, S., Ramanathan, A. L., Goswami, R., and Eslamian, S., 2015, Criterion, Indices, and Classification of Water Quality and Water Reuse Options, Urban Water Reuse Handbook, Ch. 13, Ed. By Eslamian, S., Taylor and Francis, CRC Group, USA, 163-176.

[122]Eslamian, F., Eslamian, S., and Eslamian, A., 2015, Water Reuse Guidelines for Agriculture, Urban Water Reuse Handbook, Ch. 14, Ed. By Eslamian, S., Taylor and Francis, CRC Group, USA, 177-186.

[123]Eslamian, A., Eslamian, F., and Eslamian, S., 2015, Water Reuse Guidelines for Industry, Urban Water Reuse Handbook, Ch. 15, Ed. By Eslamian, S., Taylor and Francis, CRC Group, USA, 187-194.

[124]Eslamian, S., Eslamian, F., and Eslamian, A., 2015, Water Reuse Guidelines for Recreation, Urban Water Reuse Handbook, Ch. 16, Ed. By Eslamian, S., Taylor and Francis, CRC Group, USA, 195-200.

[125]Banjoko, B. and Eslamian, S., 2015, Environmental Impact Assessment: An Application to Urban Water Reuse, Urban Water Reuse Handbook, Ch. 20, Ed. By Eslamian, S., Taylor and Francis, CRC Group, USA, 229-242.

[126]Amiri, M. J., Eslamian, S., Arshadi, M., and Khozaei, M., 2015, Water Recycling and Community, Urban Water Reuse Handbook, Ch. 22, Ed. By Eslamian, S., Taylor and Francis, CRC Group, USA, 261-274.

[127]Ferdaush, J., Noor Islam, Sh., Reinstädtler, S., and Eslamian, S., 2015, Ethical and Cultural Dimension of Water Reuse, Urban Water Reuse Handbook, Ch. 24, Ed. By Eslamian, S., Taylor and Francis, CRC Group, 285-296.

[128]Bazrkar, M. H., Zamani, N., and Eslamian, S., 2015, Evaluation of Socioeconomic Impacts of Urban Water Reuse Using System Dynamics Approach, Urban Water Reuse Handbook, Ch. 28, Ed. By Eslamian, S., Taylor and Francis, CRC Group, 331-340.

[129]Mujere, N. and Eslamian, S., 2015, Black water System, Urban Water Reuse Handbook, Ch. 33, Ed. By Eslamian, S., Taylor and Francis, CRC Group, 393-404.

[130]Abu-Ghunmi, L., and Eslamian, S., 2015, Gray water, Urban Water Reuse Handbook, Ch. 34, Ed. By Eslamian, S., Taylor and Francis, CRC Group, 405-420.

[131]Eslamian, S., Amininezhad, S. M., and Amininejad, S. M., 2015, Contamination Warning System, Urban Water Reuse Handbook, Ch. 39, Ed. By Eslamian, S., Taylor and Francis, CRC Group, 481-488. 
[132]Crusberg, T. C., and Eslamian, S., 2015, Choosing Indicators of Fecal Pollution for Wastewater Reuse Opportunities, Urban Water Reuse Handbook, Ch. 42, Ed. By Eslamian, S., Taylor and Francis, CRC Group, 511-520.

[133]Boogaard, F. and Eslamian, S, 2015, Wastewater Monitoring, Urban Water Reuse Handbook, Ch. 48, Ed. By Eslamian, S., Taylor and Francis, CRC Group, 583-586.

[134]Mujere, N., and Eslamian, S., 2015, Urban Wetland Hydrology and Water Purification, Urban Water Reuse Handbook, Ch. 50, Ed. By Eslamian, S., Taylor and Francis, CRC Group, 603-616.

[135]Nazif, S., and Eslamian, S., 2015, Urban Wetland Hydrology and Changes, Urban Water Reuse Handbook, Ch. 51, Ed. By Eslamian, S., Taylor and Francis, CRC Group, 617-640.

[136]Banjoko, B., and Eslamian, S., 2015, Phytoremediation, Urban Water Reuse Handbook, Ch. 53, Ed. By Eslamian, S., Taylor and Francis, CRC Group, 657-702.

[137]Rivas Hernández, A., Rivas Acosta, I., and Eslamian, S., .2015, Treatment Wetlands: Fundamentals, Urban Water Reuse Handbook, Ch. 54, and Ed. By Eslamian, S., Taylor and Francis, CRC Group, 703716.

[138]Rahman, A., and Eslamian, S., 2015, Rainwater Tanks as a Means of Water Reuse and Conservation in Urban Areas, Urban Water Reuse Handbook, Ch. 60, Ed. By Eslamian, S., Taylor and Francis, CRC Group, 797-808.

[139]Qian, Q., and Eslamian, S., 2015, Groundwater Recharge and Unconventional Water: Design and Management Criteria, Urban Water Reuse Handbook, Ch. 61, Ed. By Eslamian, S., Taylor and Francis, CRC Group, 809-816.

[140]Saket, R. K. and Eslamian, S., 2015, Use of Wastewater for Hydroelectric Power Generation, Urban Water Reuse Handbook, Ch. 63, Ed. By Eslamian, S., Taylor and Francis, CRC Group, 827-838.

[141]Eslamian, S., Amininezhad, S. M., Amininejad, S. M., Adamowski, J., 2015, Application of Nanotechnology in Water Reuse, Urban Water Reuse Handbook, Ch. 64, Ed. By Eslamian, S., Taylor and Francis, CRC Group, 839-844.

[142]Goodarzi, E., Ziaei, L. and Eslamian, S., 2015, Recycled Water in Basin and Farm Scales, Urban Water Reuse Handbook, Ch. 65, Ed. By Eslamian, S., Taylor and Francis, CRC Group, 855-858.

[143]Perez Sierra, J. A. and Eslamian, S., 2015, Water Reuse in Coastal Areas, Urban Water Reuse Handbook, Ch. 67, Ed. By Eslamian, S., Taylor and Francis, CRC Group, 867-874.

[144]Noor Islam, Sh., Reinstädtler, S., and Eslamian, S., 2015, Water Reuse Sustainability in Cold Climate Regions, Urban Water Reuse Handbook, Ch. 68, Ed. By Eslamian, S., Taylor and Francis, CRC Group, 875-886.

[145]Rina, K., Eslamian, S., Tyagi, G., and Singh, N., 2015, Feasibility Studies for Water Reuse Systems, Urban Water Reuse Handbook, Ch. 71, Ed. By Eslamian, S., Taylor and Francis, CRC Group, 909, 926.

[146]Salequzzaman, MD., Tariqul Islam, S. M., Shiddi quzzaman, M., and Eslamian, S., 2015. Climate Change Adaptation and Water Reuse, Urban Water Reuse Handbook, Ch. 75, Ed. By Eslamian, S., Taylor and Francis, CRC Group, 969-980.

[147]Kumar Goyal, M., Singh, V., and Eslamian, S., 2015, Impact of Climate Change on Drinking Water, Urban Water Reuse Handbook, Ch. 76, Ed. By Eslamian, S., Taylor and Francis, CRC Group, 981-1006.

[148]Hamdy, A. and Eslamian, S., 2015, Sustainable Reuse and Recycling of Treated Urban Wastewater, Urban Water Reuse Handbook, Ch. 80, Ed. By Eslamian, S., Taylor and Francis, CRC Group, 1039-1054.

[149]Thakur, J. K., Karmacharya, S., Singh, P., Gurung, D., and Eslamian, S., 2015, Water Reuse Products in Urban Areas, Urban Water Reuse Handbook, Ch. 81, Ed. By Eslamian, S., Taylor and Francis, CRC Group, 1055-1070.

[150]Eslamian, S., Sayahi, M., and Khosravi, B., 2015, Conjunctive Use of Water Reuse and Urban Water, Urban Water Reuse Handbook, Ch. 82, Ed. By Eslamian, S., Taylor and Francis, CRC Group, 1071-1078.

[151]Irfan, Z. B., and Eslamian, S., 2015, Urban Water Reuse Policy, Urban Water Reuse Handbook, Ch. 83, Ed. By Eslamian, S., Taylor and Francis, CRC Group, 1079-1096.

[152] Vafakhah, M., Eslamian, S. and Khosrobeigi Bozchaloei, S., 2014, Low-Flow Hydrology, in Handbook of Engineering Hydrology, Ch. 20, and Vol. 1: Fundamentals and Applications, Ed. By Eslamian, S., Francis and Taylor, CRC Group, USA, 433-453.

[153]Cox, J. P., Shaeri Karimi, S. and Eslamian, S., 2014, Optimum Hydrometric Site Selection, in Handbook of Engineering Hydrology, Ch. 22, and Vol. 1: Fundamentals and Applications, Ed. By Eslamian, S., Francis and Taylor, CRC Group, USA, 471-483.

[154]Eslamian, S. and Motevallian, S. S., 2014, Sustainability in Urban Water System, in Handbook of Engineering Hydrology, Ch. 27, and Vol. 1: Fundamentals and Applications, Ed. By Eslamian, S., Francis and Taylor, CRC Group, USA, 549-562. 
[155]Noor Islam, S., Karim, R., Noor Islam, A., and Eslamian, S., 2014, Wetland Hydrology, in Handbook of Engineering Hydrology, Ch. 29, and Vol. 1: Fundamentals and Applications, Ed. By Eslamian, S., Francis and Taylor, CRC Group, USA, 581-605.

[156]Gargouri-Ellouze, E. and Eslamian, S. 2014, Application of Copulas in Hydrology: Geomorphological Instantaneous Unit Hydrograph and Intensity Index of Infiltration Frequency, in Handbook of Engineering Hydrology, Ch. 1, Vol. 2: Modeling, Climate Changes and Variability, Ed. By Eslamian, S., Francis and Taylor, CRC Group, USA, 1-18.

[157]Mujere, N. and Eslamian, S. 2014, Climate Change Impacts on Hydrology and Water Resources, in Handbook of Engineering Hydrology, Ch. 7, and Vol. 2: Modeling, Climate Changes and Variability, Ed. By Eslamian, S., Francis and Taylor, CRC Group, USA, 113-126.

[158]Farzaneh, M. R., Eslamian, S. and Mirnezami, S. J. E. 2014, Climate Change: Uncertainty, Impact, and Adaptation, in Handbook of Engineering Hydrology, Ch. 8, Vol. 2: Modeling, Climate Changes and Variability, Ed. By Eslamian, S., Francis and Taylor, CRC Group, USA, 127-146.

[159]Goodarzi, E. and Eslamian, S. 2014, Dam Risk and Uncertainty, in Handbook of Engineering Hydrology, Ch. 9, and Vol. 2: Modeling, Climate Changes and Variability, Ed. By Eslamian, S., Francis and Taylor, CRC Group, USA, 147-171.

[160]Fakhri, M., Dokohaki, H., Eslamian, S., Fazeli Farsani, I. and Farzaneh, M. R. 2014, Flow and Sediment Transport Modeling in Rivers, in Handbook of Engineering Hydrology, Ch. 13, Vol. 2: Modeling, Climate Changes and Variability, Ed. By Eslamian, S., Francis and Taylor, CRC Group, USA, 233-275.

[161]Matouq, M., Al-Bilbisi, H., El-Hasan, T. and Eslamian, S. 2014, GIS Applications in a Changing Climate, in Handbook of Engineering Hydrology, Ch. 15, and Vol. 2: Modeling, Climate Changes and Variability, Ed. By Eslamian, S., Francis and Taylor, CRC Group, USA, 297-312.

[162]Noor Islam, S., Gnauck, A., Voigt, H.-J. And Eslamian, S., 2014, Hydrological Changes in Mangrove Ecosystems, in Handbook of Engineering Hydrology, Ch. 18, Vol. 2: Modeling, Climate Changes and Variability, Ed. By Eslamian, S., Francis and Taylor, CRC Group, USA, 353-373.

[163]Kałuża, T. and Eslamian, S. 2014, Impact of the Development of Vegetation on Flow Conditions and Flood Hazards, in Handbook of Engineering Hydrology, Ch. 21, Vol. 2: Modeling, Climate Changes and Variability, Ed. By Eslamian, S., Francis and Taylor, CRC Group, USA, 415-449.

[164]Rahman, A., Haddad, Kh. and Eslamian, S., 2014, Regional Flood Frequency Analysis, 2014, in Handbook of Engineering Hydrology, Ch. 22, and Vol. 2: Modeling, Climate Changes and Variability, Ed. By Eslamian, S., Francis and Taylor, CRC Group, USA, 451-469.

[165]Vafakhah, M. and Eslamian, S. 2014, Regionalization of Hydrological Variables, in Handbook of Engineering Hydrology, Ch. 23, and Vol. 2: Modeling, Climate Changes and Variability, Ed. By Eslamian, S., Francis and Taylor, CRC Group, USA, 471-499.

[166]Chowdhury, R. K. And Eslamian, S. 2014, Statistical Parameters Used for Assessing Hydrological Regime, in Handbook of Engineering Hydrology, Ch. 26, Vol. 2: Modeling, Climate Changes and Variability, Ed. By Eslamian, S., Francis and Taylor, CRC Group, USA, 537-551.

[167]Mujere, N. and Eslamian, S. 2014, Impact of Urbanization on Runoff Regime, Chowdhury, R. K. and Eslamian, S. 2014; Statistical Parameters Used for Assessing Hydrological Regime, in Handbook of Engineering Hydrology, Ch. 29, Vol. 2: Modeling, Climate Changes and Variability, Ed. By Eslamian, S., Francis and Taylor, CRC Group, USA, 605-615.

[168]Gaaloul, N. and Eslamian, S., 2014, Artificial Recharge Experiences in Semiarid Areas, in Handbook of Engineering Hydrology, Ch. 2, Vol. 3: Environmental Hydrology and Water Management, Ed. By Eslamian, S., Francis and Taylor, CRC Group, USA, 17-49.

[169]Amininezhad, S. M., Amininejad, S. M., and Eslamian, S., 2014, Disinfection of Water and Nanotechnology, in Handbook of Engineering Hydrology, Ch. 3, and Vol. 3: Environmental Hydrology and Water Management, Ed. By Eslamian, S., Francis and Taylor, CRC Group, USA, 51-64.

[170]Shaeri Karimi, S., Yasi, M., Cox, J. P., and Eslamian, S., 2014, Environmental Flows, in Handbook of Engineering Hydrology, Ch. 5, and Vol. 3: Environmental Hydrology and Water Management, Ed. By Eslamian, S., Francis and Taylor, CRC Group, USA, 85-104.

[171]Eslamian, S., Malekian, R., and Amiri, M. J. 2014, Environmental Nanotechnology, in Handbook of Engineering Hydrology, Ch. 6, and Vol. 3: Environmental Hydrology and Water Management, Ed. By Eslamian, S., Francis and Taylor, CRC Group, USA, 105-118.

[172]Deiminiat, A., and Eslamian, S., 2014, River Managed System for Flood Defense, in Handbook of Engineering Hydrology, Ch. 14, Vol. 3: Environmental Hydrology and Water Management, Ed. By Eslamian, S., Francis and Taylor, CRC Group, USA, 299-314.

[173]Deiminiat, A., Hassan Shojaee Siuki, and Eslamian, S. 2014, Tourism and River Environment, in Handbook of Engineering Hydrology, Ch. 20, and Vol. 3: Environmental Hydrology and Water Management, Ed. By Eslamian, S., Francis and Taylor, CRC Group, USA, 401-419. 
[174]Green, C. and Eslamian, S., 2014, Water Governance, in Handbook of Engineering Hydrology, Ch. 24, and Vol. 3: Environmental Hydrology and Water Management, Ed. By Eslamian, S., Francis and Taylor, CRC Group, USA, 461-483.

[175]Eslamian, F. and Eslamian S., 2014, Water Pollution Control Using Low-Cost Natural Wastes, in Handbook of Engineering Hydrology, Ch. 25, Vol. 3: Environmental Hydrology and Water Management, Ed. By Eslamian, S., Francis and Taylor, CRC Group, USA, 485-499.

[176]He, Ch., Zhang, L., Zhang, X., and Eslamian, S., 2014, Water Security: Concept, Measurement, and Operationalization, in Handbook of Engineering Hydrology, Ch. 28, and Vol. 3: Environmental Hydrology and Water Management, Ed. By Eslamian, S., Francis and Taylor, CRC Group, USA, 545-554.

[177]Fakhri, M., Farzaneh, M. R., Eslamian S. and Nazari, R., 2013, Wind speed regionalization under climate change conditions, Chapter 10, New Developments in Renewable Energy by H. Arman \& I. Yukcel, 215236.

[178]Nazari, R., Khanbilvardi, R., Hoyos, S., and Eslamian, S., 2013, Freshwater Demands and Storages, Encyclopedia of Crises Management, Sage Publication.

[179]Eslamian, S., 2012, Forecasting, Encyclopedia of Energy, Salem Press, USA, 461-464

[180]Eslamian, S., 2012, Iran, Encyclopedia of Energy, Salem Press, USA, 708-713.

[181]Eslamian, S. and Nazari, R., 2012, Nebraska, Encyclopedia of Energy, Salem Press, USA, 889-893.

[182]Nazari, R., S. Eslamian and R. Khanbilvardi, 2012, Water Reuse and Sustainability, Chapter 11, in Ecological Water Quality-Water Treatment and Reuse by K. Voudouris and D. Vousta, 241-254, Intech.

[183]Eslamian, S. S., Gilroy K. L. and R. H. McCuen, 2011, Climate Change Detection and Modeling in Hydrology, Ch. 5 in "Climate Change -Research and Technology for Adaptation and Mitigation" Edited by J. Blanco and H. Kheradmand, InTech, 87-100.

Citation: K. O. A. Askari, "Investigating Water Use efficiency of Potato in Chaharmahal and Bakhtiari Province Compared to Alternate Furrow Irrigation Method, Iran", International Journal of Research Studies in Agricultural Sciences, vol. 4, no. 1, p. 12-24, 2018. http://dx.doi.org/10.20431/2454-6224.0401003

Copyright: (C) 2018 Authors. This is an open-access article distributed under the terms of the Creative Commons Attribution License, which permits unrestricted use, distribution, and reproduction in any medium, provided the original author and source are credited. 